Article

\title{
Absorption and Photo-Stability of Substituted Dibenzoylmethanes and Chalcones as UVA Filters
}

\author{
Silvina Quintana Lazópulos ${ }^{1,+}$, Federico Svarc ${ }^{2, *} \mathbb{1}$, Gabriel Sagrera ${ }^{3}$ and Lelia Dicelio ${ }^{2}$ \\ 1 fabriQUIMICA S.R.L. R\&D, Buenos Aires B1650IJA, Argentina; silvinalazopulos@gmail.com \\ 2 Facultad de Ciencias Exactas y Naturales UBA. DQIAQF-INQUIMAE, Buenos Aires C1428EGA, Argentina; \\ lelia.dicelio@gmail.com \\ 3 Facultad de Química UDELAR. Departamento de Química Orgánica, Montevideo 11800, Uruguay; \\ gjsagrera@gmail.com \\ * Correspondence: fsvarc@qi.fcen.uba.ar; Tel.: +54-91153394217 \\ + Current address: BASF Argentina S.A., Buenos Aires C1049AAA, Argentina.
}

Received: 2 March 2018; Accepted: 10 May 2018; Published: 17 May 2018

\begin{abstract}
There is still an international need to develop broad-spectrum sunscreen products with an adequate UVB/UVA balance, while the approved filters available in the UVA are scarce. Currently, one of the few UVA filters approved in the United States and Europe is tert-butylmethoxydibenzoylmethane (BMDM, avobenzone). However, this compound is unstable from aphotochemical point of view and cannot be used in combination with certain sunscreens. In this paper, we investigate the photochemical behavior of a set of dibenzoylmethanes and chalcones. In particular, we carry out their absorption and emission spectra, evaluate their photochemical degradation, and study their generation of free radicals and singlet oxygen photoproduction. Two compounds resultedin having the basic properties of UVA filters (2'-hydroxy-4-methoxychalcone and $2^{\prime}$-hydroxy-4-methoxydibenzoylmethane). Further studies are proposed, such as formulating the compounds into emulsions or other common cosmetic presentations, as well as combining them with broadly-used UVB filters. We have also considered the need to establish its toxicological profile.
\end{abstract}

Keywords: UVA filters; dibenzoylmethanes; chalcones; photo-stability

\section{Introduction}

Moderate exposure to sunlight has several beneficial effects on human health [1-3]. However, excessive exposure to UV radiation causes various damages to the body, including burns, photoaging and skin cancer [4-6]. The first commercially-available sunscreen appeared in 1928, it contained benzyl salicylate and benzyl cinnamate [7]. Currently, these substances are, not only incorporated in sunscreens, but also in a large number of cosmetics for skin and haircare [7].

Different substances are approved as solar filters for humans, according to regional requirements. According to Shaath [8], in 2010, there were 55 UV filters approved in different parts of the world; of these, only 10 were globally approved.

Currently-authorized UV filters are classified into two types: Inorganic and organic. The inorganic filters used are $\mathrm{ZnO}$ and $\mathrm{TiO}_{2}$. Both are considered broad spectrum because they absorb or reflect UVB and UVA rays. Organic filters are classified according to their structure (Figure 1). There are several important aspects to be taken into account, such as the photostability of the sunscreen, its toxicity in humans, and its final disposal into the environment. 
<smiles>[R]N([O-])c1ccc(C(=O)OCC)cc1</smiles>

4-aminobenzoates<smiles>CCOC(=O)C=Cc1ccc(OC(=O)OC)cc1</smiles>

cinnamates<smiles>[R]OC(=O)c1ccccc1O</smiles>

salicylates<smiles>[R]OC(=O)c1ccccc1N</smiles><smiles>[R]C1CCCCC1</smiles><smiles>[R]Cc1ccccc1C(=O)CC(=O)c1ccc([R])cc1</smiles>

anthranilates

benzophenones<smiles>[R]c1ccc(C=C2CC3CCC(C)(C2=O)C3(C)C)cc1</smiles><smiles>[R][R]1cccc(-c2nc3ccc([R])cc3[nH]2)c1</smiles>

camphor derivatives<smiles>[R2]c1cccc(-c2nc(-c3ccccc3)nc(-c3ccccc3)n2)c1</smiles>

Figure 1. General structures of the most important currently-approved organic filters.

Photodegradation causes a loss of UV protection because of resulting photoproducts that show UV-absorption at lower wavelengths than their parent compounds [9-11]. For example, nano- $\mathrm{TiO}_{2}$ (particle size $<25 \mathrm{~nm}$ ) causes photodegradation of avobenzone (BMDM) and octocrylene (OC) [12]. An important issue to be considered at the level of skin or percutaneous absorption is the toxicity of sunscreens, either per se or caused by their decomposition products.

In the 1980s, 4-isopropyldibenzoylmethane was used as a sunscreen, but in 1993 it was eliminated from the market for causing allergies. It was only in this century that we became fully aware of the need to obtain an adequate balance of UVB/UVA protection; legislation and control methods are still not in full agreement [13]. Currently, one of the few UVA filters approved in the United States and Europe is tert-butylmethoxydibenzoylmethane (avobenzone), which shows light absorption $\lambda_{\max }=357 \mathrm{~nm}$. However, this compound is unstable from the photochemical point of view and can't be used in combination with certain sunscreens.

Recent studies show that the irradiation of avobenzone causes a breakdown of the molecule in radicals, this generates compounds, such as arylglyoxals and benzyls (Figure 2) [14], or react with other sunscreens [15]. In Figure 2, $\mathrm{H}^{\bullet}$ refers to the capture of a hydrogen atom from another molecule (generally the solvent). Studies of the biological properties of photodecomposition products indicate that arylglyoxals are strong photosensitizers. They are also very electrophilic and react quickly with arginine of proteins. On the other hand, benzyls are cytotoxic [6].

Different ways to photostabilize avobenzone have been reported. Among them are UV pearls (encapsulated sunscreens), microspheres (hollow spheres of styrene-acrylate copolymers), ROS (reactive oxygen species) trappers, and inhibitors of the triplet-triplet and singlet-singlet mechanism [8]. Moreover, several patents have been published claiming different strategies to solve the intrinsic instability of dibenzoylmethane compounds subjected to UV radiation, such as synthesizing diorgano-polysiloxane derivatives or derivatives of other polymers [16], including the formulation of esters or diesters of $\alpha$-naphthalenesulphonic acid [17]. Two ideas were also proposed, firstly to include in the formulas a thickening polymer, having a small polar tail from an $\alpha, \beta$-unsaturated monocarboxylic acid, linked to a heavier non-polar moiety of alkyl-methacrylate or alkylstyrene 
polymer [18]; secondly, to synthesize a quaternary compound of dibenzoylmethane [19]. Finally, it was also proposed to protect avobenzone with anti-oxidants such as vitamins C and E [20].

Some authors have tried to switch the keto-enoltautomerism of avobenzone (whose enol structure is more stable to radiation) by introducing different substituents to the aromatic rings and consequently modifying the absorption maxima wavelength and intensity [21-24]. These different substituents include chlorides, fluorides, acetamides, hydroxy, methoxy and nitro groups, and long aliphatic chains. None of these proposals seem to have been successful. The solution should not be to use photochemically unstable molecules that require additional molecules to make them stable in a cosmetic formulation. According to Gonzenbach [25], using a UV filter to avoid photodecomposition of another UV filter is similar to protecting an umbrella from getting wet by placing a second umbrella over it. If the umbrella does not repel the rain, it must be improved in some way.

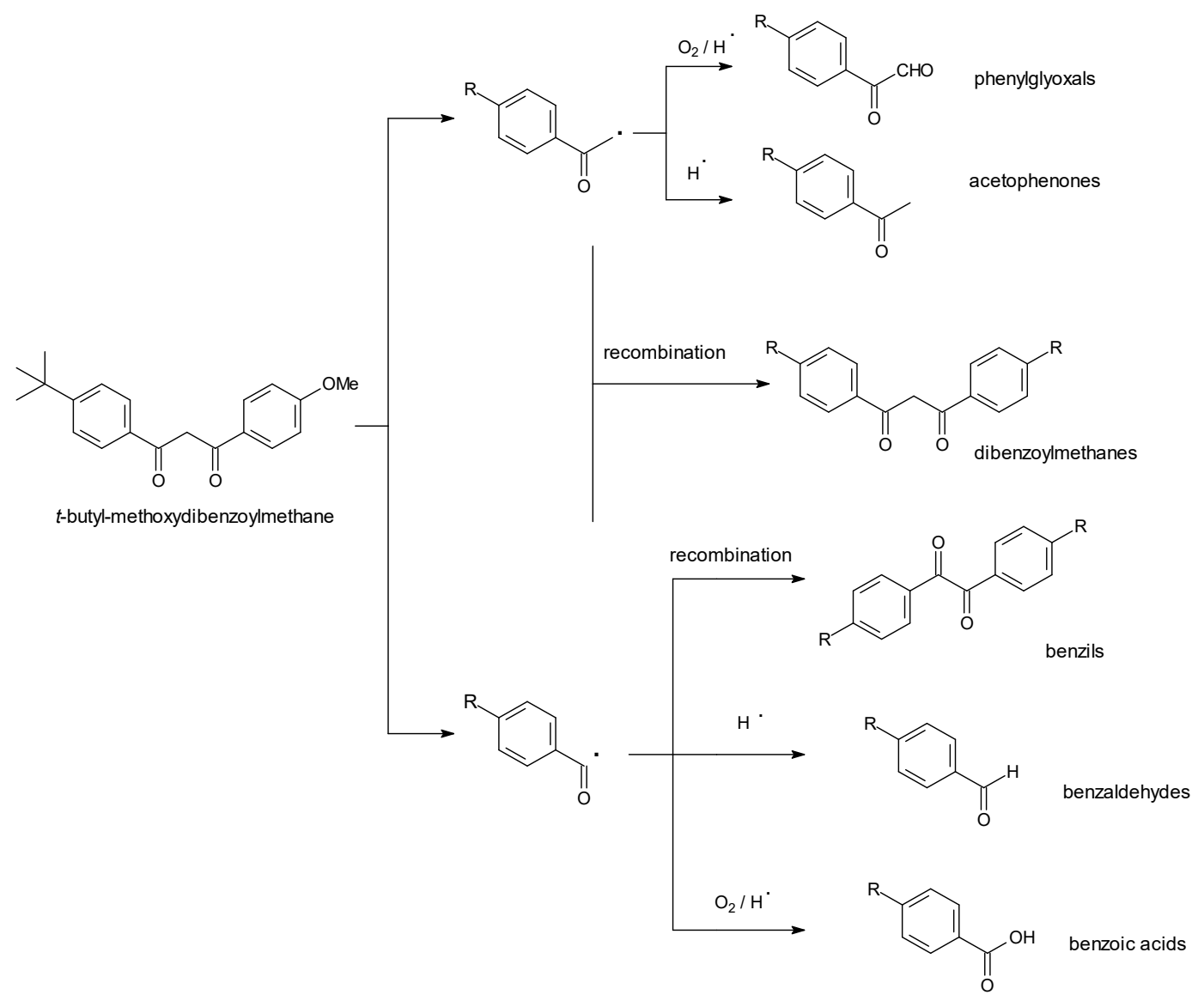

Figure 2. Photodegradation of dibenzoylmethanes (adapted from Schwack et al. [11]).

On the other hand, several studies have been made both in solution [11], formulated into emulsions, or by irradiating a thin film to simulate application to the skin [26].

It must be noted that none of the compounds previously studied belong to the set tested in our work. In almost every case, when subjected to the radiation of solar simulators, they showed decomposition in the range of 3.6 to $40 \%$. When dissolved in non-polar solvents they decomposed easily; however, the stability improved when short chain alcohols, such as methanol and isopropanol were used as solvents. Deflandre and Lang [26] also found more stability when an -OH was present at the ortho position to a carbonyl group. Other recent studies [27] show that the keto-enol tautomerism not only shifts the absorption maxima, but it is also responsible for the photo-degradation of the molecules.

Another important problem is environmental pollution. Because coastal tourism is rapidly growing, sunscreen is now considered an emerging pollutant [28]. Sunscreens are formulated to resist 
being washed out while bathing, however, it is estimated that after $20 \mathrm{~min}$ of immersion, $25 \%$ of the ingredients are released into the water. Several ecological problems have been reported in recent years [29-34].

Chalcones are a type of flavonoid with the structure $\mathrm{C}_{6}-\mathrm{C}_{3}-\mathrm{C}_{6}$ and are widely distributed in the vegetable kingdom. Many natural and synthetic chalcones have some kind of biological activity in animals and humans, or are used in industries. Chalcones have $\lambda_{\max } \sim 350 \mathrm{~nm}$, so are useful as UV absorbers and can be incorporated in paints, plastics, synthetic fibers and cosmetics [35-38]. Lahorkar reported that some chalcones (butein, monospermoside) enhance the stability of avobenzone [39].

Considering this background, and due to the growing demand for sunscreen, the discovery of new, safer and more effective compounds is of great importance. In this paper we describe the photochemical behavior of a small set of dibenzoylmethanes and chalcones. More specifically, we have carried out their absorption and emission spectra, evaluated their photochemical degradation and studied their generation of free radicals and singlet oxygen photoproduction.

\section{Materials and Methods}

The following compounds were tested (Figure 3):

Dibenzoylmethanes:

(a) 1-(2-hydroxyphenyl)-3-phenyl-1,3-propanedione (DBM1)

(b) 1-(2-hydroxyphenyl)-3-(4-methylphenyl)-1,3-propanedione (DBM2)

(c) 1-(2-hydroxyphenyl)-3-(4-methoxyphenyl)-1,3-propanedione (DBM11)

(d) (4E)-1-(2-hydroxyphenyl)-5-phenyl-4-penten-1,3-dione (DBM4)

Chalcones:

(e) (2E)-1,3-diphenyl-2-propen-1-one (CH00)

(f) (2E)-1-(2-hydroxyphenyl)-3-(4-methoxyphenyl)-2-propen-1-one (CH11)

(g) 1-(2-hydroxyphenyl)-5-phenyl-(2E,4E)-2,4-pentadien-1-one (CHClN)<smiles>O=C(CC(=O)c1ccccc1O)c1ccccc1</smiles><smiles>Cc1ccc(C(=O)CC(=O)c2ccccc2O)cc1</smiles>

DBM2<smiles>COc1ccc(C(=O)CC(=O)c2ccccc2O)cc1</smiles><smiles>O=C(/C=C/c1ccccc1)CC(=O)c1ccccc1O</smiles><smiles>O=C(O)/C=C/c1ccccc1</smiles><smiles>COc1ccc(/C=C/C(=O)c2ccccc2O)cc1</smiles><smiles>N#CC(=O)c1ccccc1O</smiles>

Figure 3. Dibenzoylmethanesand chalcones tested in this study.

All compounds were synthesized, purified and characterized at the Department of Organic Chemistry, Universidad de la República (UDELAR), Montevideo, Uruguay. The chalcones were prepared by aldol condensation of the corresponding 2'-hydroxyacetophenones and benzaldehydes [40]. The dibenzoylmethanes were prepared using Baker-Venkataraman rearrangement, which rearranged the corresponding 2-acetyl phenyl benzoates [41]. All compounds were purified by column chromatography and characterized by ${ }^{1} \mathrm{H}-\mathrm{NMR},{ }^{13} \mathrm{C}-\mathrm{NMR}$, mass spectrometry, and elemental analysis. 
The spectroscopic and photochemical studies were performed at the INQUIMAE (Instituto de Química Física de los Materiales, Medio Ambiente y Energía), CONICET (Consejo Nacional de Investigaciones Cientificas y Tecnicas) and FCEN (Facultad de Ciencias Exactas y Naturales), Universidad de Buenos Aires (UBA). The samples a-g were dissolved in absolute Ethanol P.A. and scanned between 200 and $500 \mathrm{~nm}$ with aUV-VIS Shimadzu UV-3600 spectrophotometer (Shimadzu Corp., Kyoto, Japan) to obtain their absorption spectra. The emission spectra and the calculations used to obtain the quantum fluorescence yields, were performed between 400 and $650 \mathrm{~nm}$ with Photon Technology International QM-1 spectrofluorometer (Photon Technology Inc., Birmingham, NJ, USA). The excitation wavelengths used coincided with the absorption maxima of each substance.

To measure photo-stability, the samples were subjected for two hours to the radiation of a solar simulator (290-340 nm). The experiments were done usinga quartz Philips 7748SEHJ lamp (24 V-250 W, Philips Lightening, Amsterdam, The Netherlands), which has a UV-transparent quartz bulb with XHP technology and is an alternative to classical Xe sources. The lamp was then collimated with an adequate lens and further filtered through a $10 \mathrm{~cm}$ water filter to eliminate the IR radiation. A cut off filter Schott UG11 was also interposed in the optical path of the sample to eliminate the UVC radiation.

The UV radiation incident placed perpendicular to a $10 \times 10 \mathrm{~mm}$ stirred quartz cell containing the sample solutions through a limiting window. The spectral distribution obtained was similar to the one of commercial sources manufactured by Berger [42]. The calculated irradiance, estimated with Field Master equipment during the first set of tests, was of $105.5 \mu \mathrm{W} / \mathrm{cm}^{2}$; later on it was increased by shortening the optical pass to $8.56 \mathrm{~mW} / \mathrm{cm}^{2}$ for the more promising samples.

In all cases, Lambert-Beer's law was verified. The singlet oxygen studies were performed employing difenilisobenzofurane (DBPF) as the control molecule [43]. The fluorophore incorporated to verify free radical generation was $2^{\prime}, 7^{\prime}$-dichlorodihydrofluorescindiacetate, which is a probe that becomes fluorescent under oxidation and emits a green color. The quantum yields were obtained taking rhodamine 101 dissolved in ethanol $\left(\Phi_{\mathrm{F}}=0.96\right)$ as a references $[43,44]$.

\section{Results}

\subsection{Absorption Spectra}

Figure $4 \mathrm{~A}-\mathrm{D}$ shows the absorption spectra obtained for the dibenzoylmethanes and the different concentrations tested for each one of the four samples in this study.

Concentrations are expressed as weight/volume \% (P/V \%).

Figure $5 \mathrm{~A}-\mathrm{C}$ shows the absorption spectra obtained for the three chalcones tested under this study. Concentrations are expressed as weight/volume \% (P/V \%).
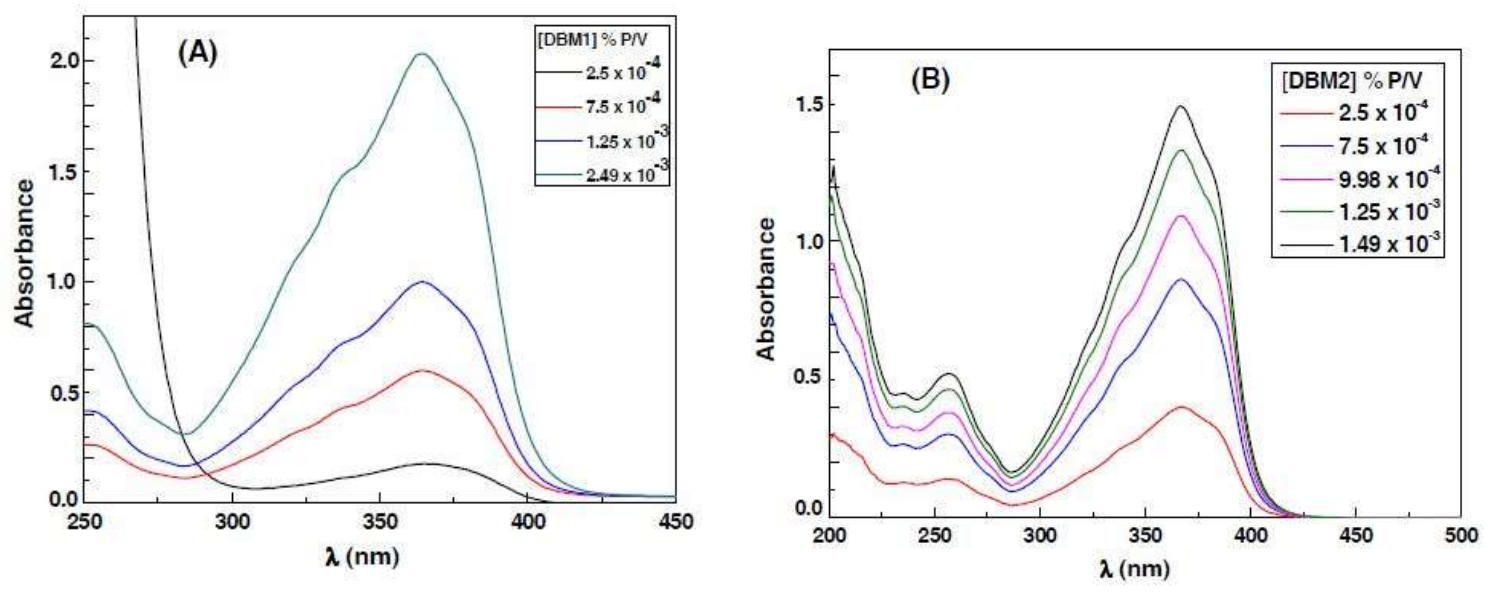

Figure 4. Cont. 

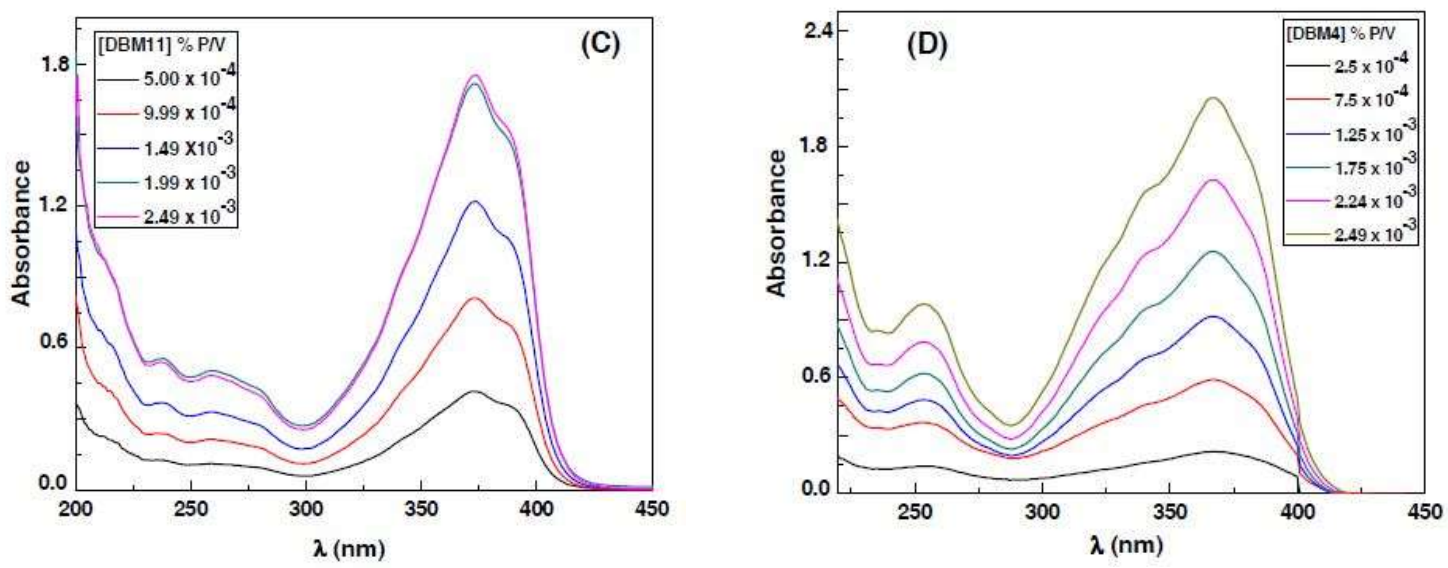

Figure 4. Absorption spectra of dibenzoylmethanes: (A) DBM1; (B) DBM2; (C) DBM11; (D) DBM4.
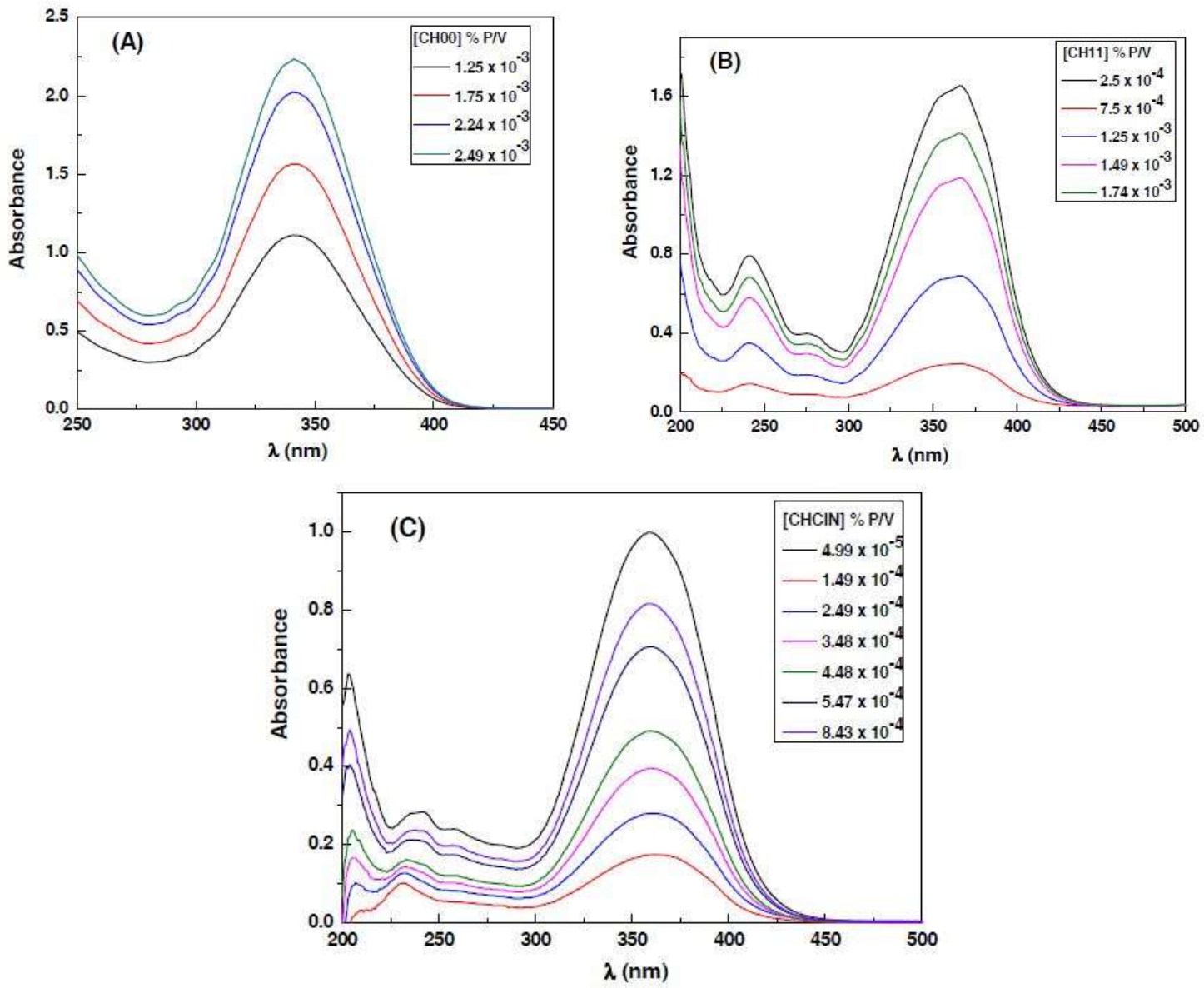

Figure 5. Absorption spectra of chalcones: (A) $\mathrm{CH} 00$; (B) $\mathrm{CH} 11$; (C) CHCIN.

In the latter case, we found that the absorption maxima of chalcones were close to the formerly studied dibenzoylmethane compounds. Thus, they could also be used in combination with UVB filters to formulate broad-spectrum sunscreens.

\subsection{Emission Spectra}

Figure 6 shows the emission spectra obtained from the different filters tested. 


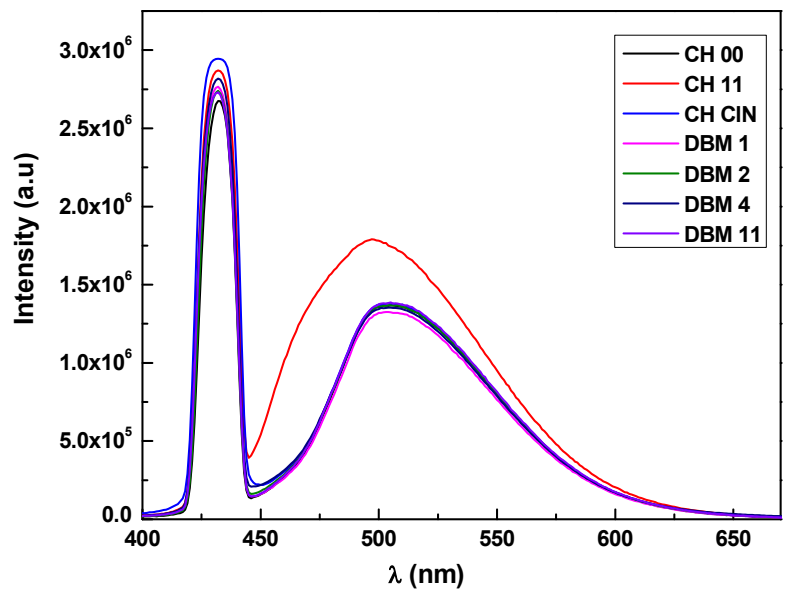

Figure 6. Fluorescence spectra of the different compounds tested.

The quantum yields obtained for all the tested compounds, relative to Rhodamine as a fluorescent probe (Table 1), were very feeble.

The experimental results show a low quantum fluorescence yield and no generation of free radicals or singlet molecular oxygen; therefore, the only way of decaying to ground state is through energy transfer as heat to the environment.

Table 1. Quantum yields relative to rhodamine 101 in ethanol $\left(\Phi_{\mathrm{F}}=0.96\right)$.

\begin{tabular}{ccccc}
\hline Sample & $\begin{array}{c}\text { Absorption at } \\
\boldsymbol{\lambda}=\mathbf{3 5 0} \mathbf{~ n m}\end{array}$ & Emission Area & $\begin{array}{c}\text { Absorption } \\
\text { Intensity }\end{array}$ & $\begin{array}{c}\text { Quantum Yield } \\
\text { (Fluorescence) }\end{array}$ \\
\hline Rod 101 & 0.0134 & 528628676.92 & 0.03038 & 0.96 \\
DBM 1 & 0.1387 & 162205046.87 & 0.27339 & 0.033 \\
DBM 2 & 0.3064 & 99573752.80 & 0.50614 & 0.011 \\
DBM4 & 0.1788 & 169868850.73 & 0.33747 & 0.028 \\
DBM11 & 0.3223 & 168263751.04 & 0.52389 & 0.018 \\
CH00 & 0.1736 & 162546475.64 & 0.32949 & 0.027 \\
CH11 & 0.2316 & 225362192.66 & 0.41332 & 0.030 \\
CHClN & 0.3777 & 179803227.87 & 0.58092 & 0.017 \\
\hline
\end{tabular}

\subsection{Decomposition Kinetics}

Figure 7A-D (for the dibenzoylmethanes) and Figure 8A-C (for the substituted chalcones) show what happened when the samples were irradiated with $105.5 \mu \mathrm{W} / \mathrm{cm}^{2}$ UV light for two hours. Concentrations are expressed as weight/volume \% (P/V \%).
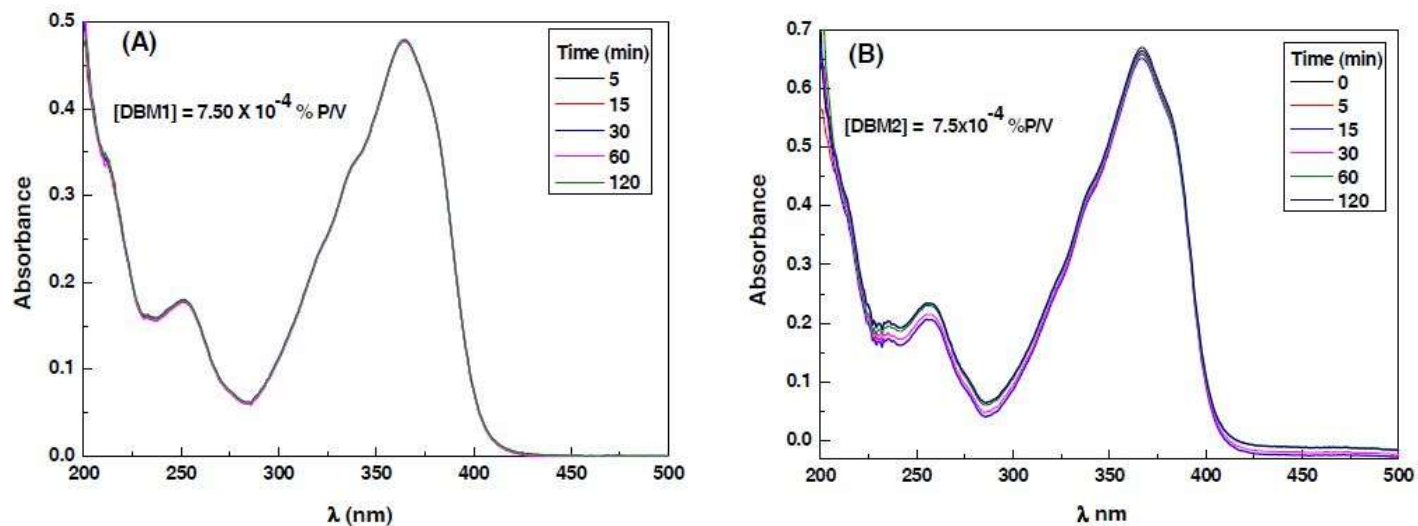

Figure 7. Cont. 

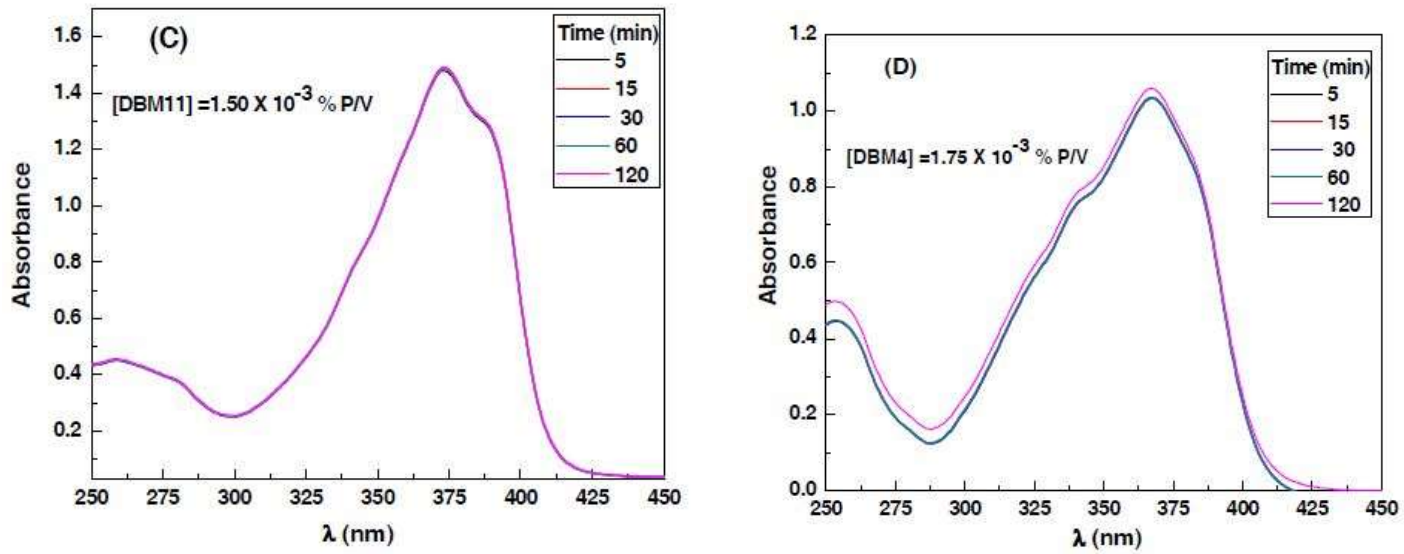

Figure 7. Photodecomposition of dibenzoylmethanes: (A) DBM1; (B) DBM2; (C) DBM11; (D) DBM4.
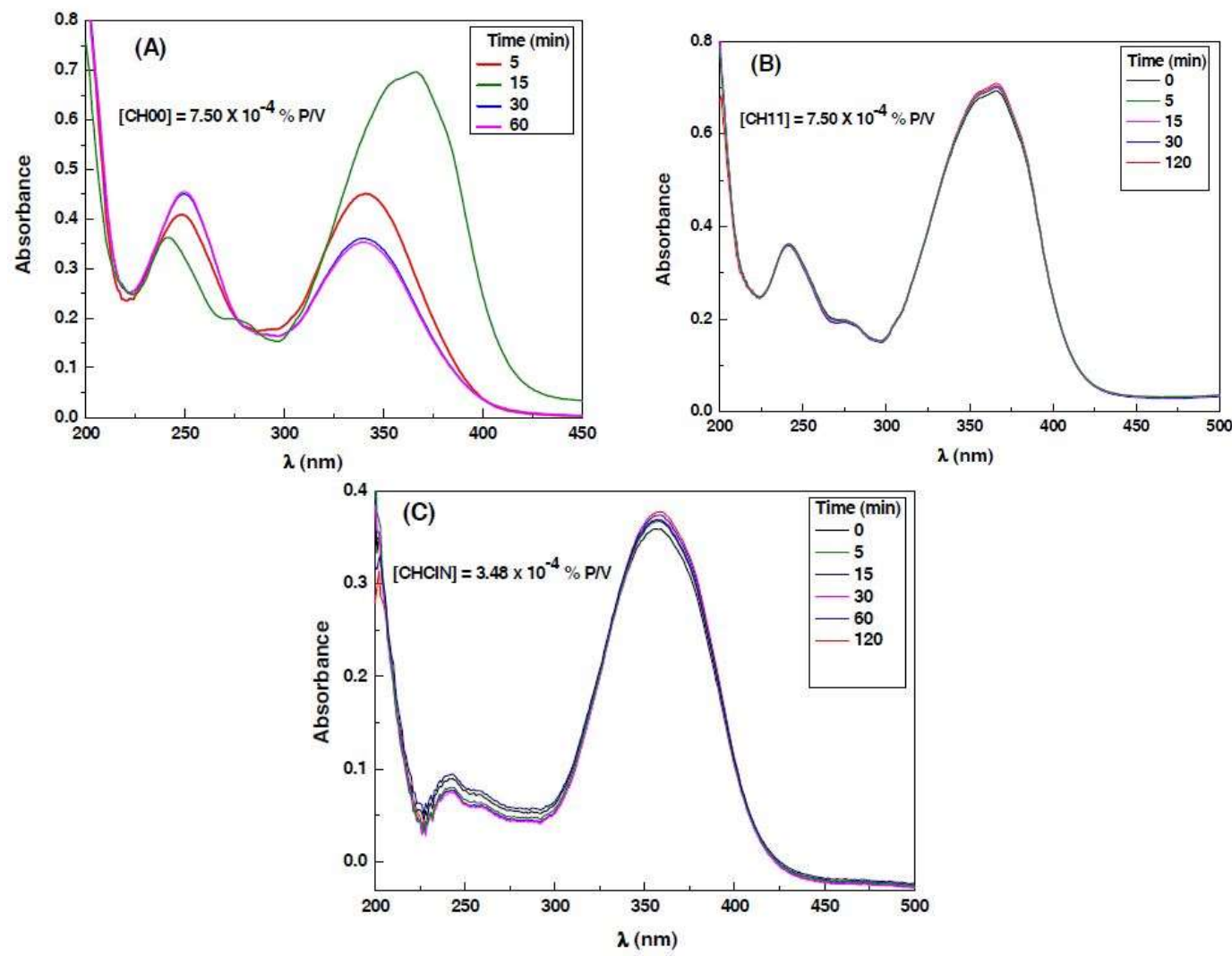

Figure 8. Photodecomposition of chalcones: (A) CH00; (B) $\mathrm{CH} 11$; (C) $\mathrm{CHCIN}$.

The two more stable dibenzoylmethanes, when submitted to UV irradiation from our solar simulator, were DBM1 and DBM11. We decided to continue further with DBM11 because it had a better fluorescence profile (the lowest within the stable molecules). The unsubstituted chalcone was extremely unstable, showing almost 50\% decomposition after one hour. Instead, $\mathrm{CH} 11$ proved to be quite stable during our experiment.

\subsection{Singlet Oxygen and Free Radicals Studies}

Figure $9 \mathrm{~A}, \mathrm{~B}$ corresponds to the singlet oxygen studies in the presence of difenilisobenzofurane (DBPF). The black line corresponds to DBPF alone, the red one to $\mathrm{CH} 11$ or DBM11 alone, while the other colors correspond to the mixtures of DBPF with the two filters at different times of irradiation. 
No significant variations were detected in their absorption; the two stable compounds did not generate singlet oxygen when they were irradiated in the presence of DPBF.

Neither did we detect the generation of free radicals by fluorescence when the mixtures of DBM11 and $\mathrm{CH} 11$ with dichlorofluorescein were irradiated with UV light.
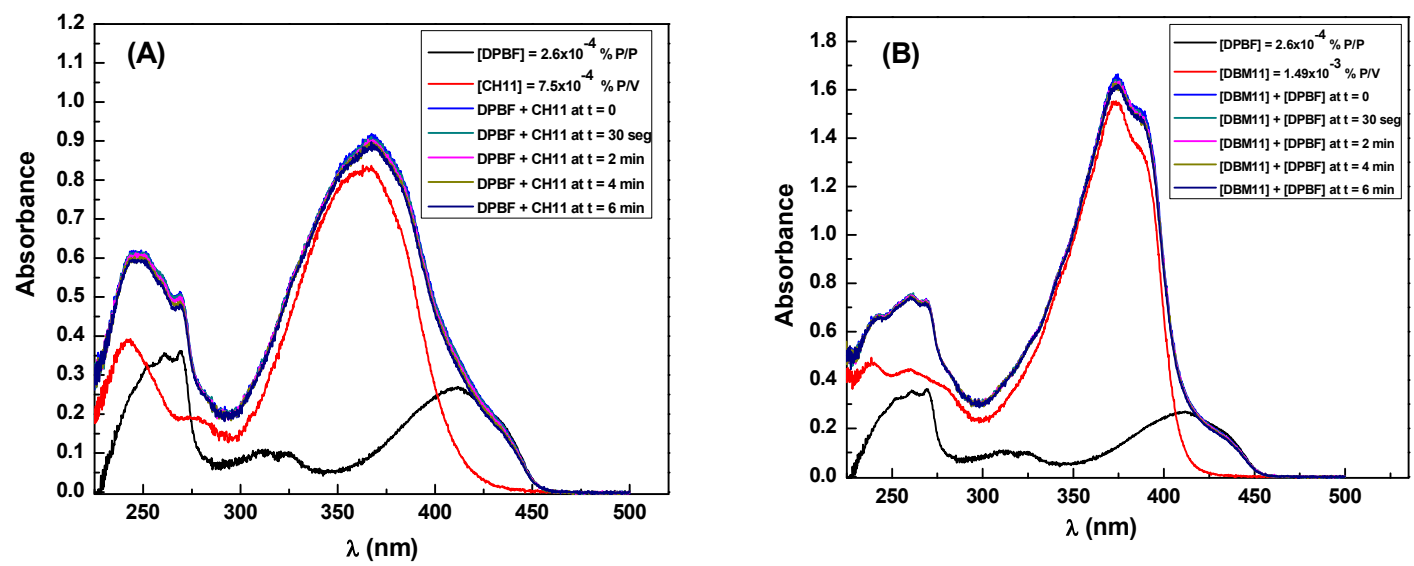

Figure 9. Spectra of CH11 (A) and DBM11 (B) mixed with difenilisobenzofurane (DPBF).

\subsection{Decomposition Kinetics under More Stringent Conditions}

Figure 10A,B shows the samples behavior when irradiated for two hours with $8.56 \mathrm{~mW} / \mathrm{cm}^{2}$ light. Concentrations are expressed as weight/volume $\%(\mathrm{P} / \mathrm{V} \%)$.
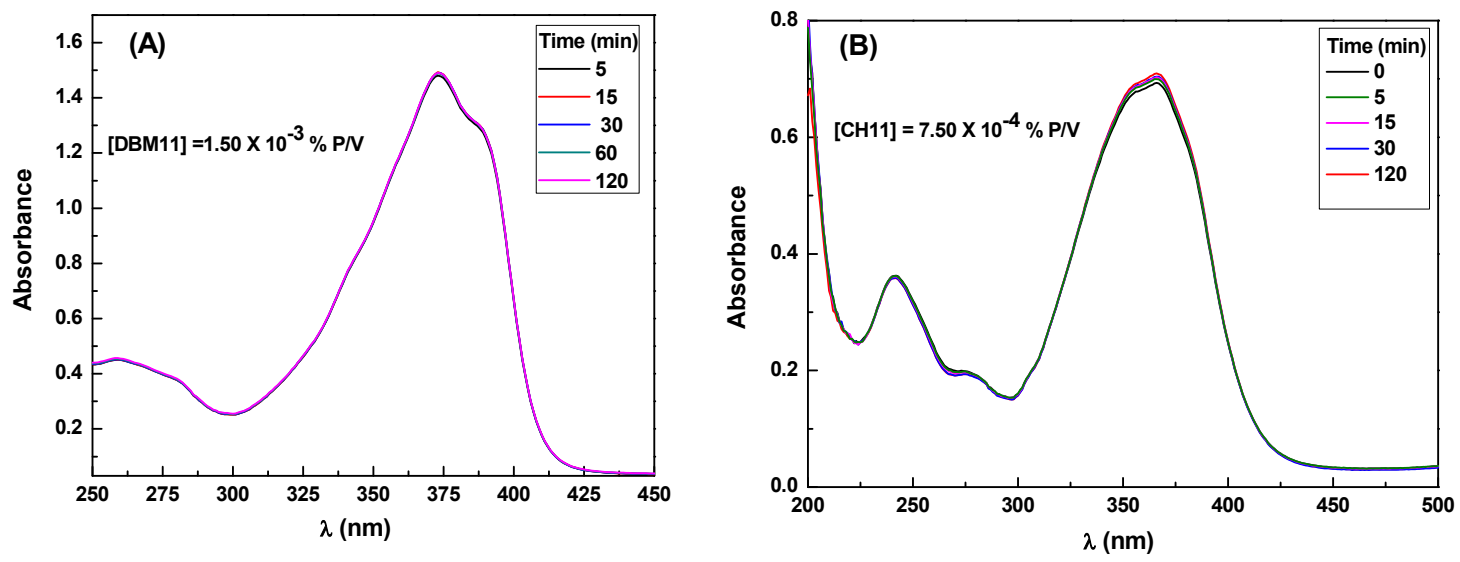

Figure 10. Photodecomposition of DBM11: (A) and CH11 (B) with $8.56 \mathrm{~mW} / \mathrm{cm}^{2}$.

Results show that DBM11 was not degraded by irradiation, while $\mathrm{CH} 11$ suffered a very small degree of degradation, estimated at $1.3 \%$ from the areas under the curves.

\section{Discussion}

Two out of the seven compounds studied are promissory to be considered as potential UVA filters: 2'-hydroxy-4 methoxy chalcone (CH11) and 2'-hydroxy-4-methoxydibenzoylmethane (DBM11). Both were able to resist a UV irradiationof $8.56 \mathrm{~mW} / \mathrm{cm}^{2}$ for two hours, receiving an accumulated energy of $61.6 \mathrm{~J} / \mathrm{cm}^{2}$.

The DBM 11 sample showed practically zero decomposition, while the $\mathrm{CH} 11$ sample lost $1.3 \%$ of the original concentration, as calculated from the area under the curve. We estimated that the total power delivered in this battery of tests corresponds to double what a sample would receive as a mean in America during summer between the $+25 \mathrm{~N}$ and $-25 \mathrm{~S}$ parallels [45]. 
On the other hand, the energy absorbed by these two compounds in the UV is dissipated mostly as heat and very little as fluorescence. Moreover, during the decay, they do not generate reactive species (singlet oxygen or free radicals) that could damage the skin during the process, as shown in Section 3.4.

They present the basic characteristics of actual chemical UV filters: they have aromatic structures conjugated with carbonyl groups that absorb energy from the photons UV radiation and by means of resonance delocalization, jump to an excited state. Then they decay to their fundamental state emitting energy of longer wavelengths into the infrared (as heat) or visible fluorescence, satisfying the laws of energy conservation [46,47].

The other possible route of decay is by photochemical reactions that generate non-desired by-products that could be irritating, toxic [11], or even react with other filters in the formulations, impairing their protective action to the skin.

The results obtained up to this stage, leadus to think that we have found two possible candidates that deserve further study. Both present absorption maxima in the range of 350-370 nm and show good photostability when dissolved in low molecular weight alcohol (ethanol). These two molecules would meet the need that consumers, formulators, and the whole industry are looking for: better sunscreens with adequate UVB/UVA balance, without having to resort to gadgets to protect other essentially unstable molecules.

We will continue our studies to verify if once formulated into an emulsion and combined with other filters, namely UVB filters as 2-ethylhexylmethoxy cinnamate or octyltriazone, they keep their stability when a thin film of the product $[26,46,48,49]$ is irradiated with a solar simulator and if this process does not generate undesirable decay by-products. We also envisage toxicological in vitro assays on the pure materials and in the formulations to establish a toxicological profile and the future possibility of predicting their spectral properties by in silico studies, based on density functional theory [50].

In fact, the latter is already underway by the research team of Dr. Darío Estrin at DQIAQF-INQUIMAE. FCEN-UBA.

\section{Conclusions}

We identified two molecules that have the basic properties of the UVA filters. They present an absorption maximum in the range of 350-370 $\mathrm{nm}$. When irradiated they jump from the ground state to an excited one, decaying basically by emission in the IR. Almost no visible emission is detected (fluorescence). We did not detect any decomposition in the case of 2'-hydroxy-4methoxydibenzoylmethane (DBM11) and only a very slight one for 2 '-hydroxy-4 methoxy chalcone (CH11). Generation of singlet molecular oxygen and free radicals was not detected either. We can confirm that if an - $\mathrm{OH}$ group is positioned at the ortho position of carbonyl, then both molecules are more stable. Furthermore, both have a methoxy group in position 4 , which caused us to think that in terms of delocalization of electrons, there exists similitudes that could explain their favorable behavior under UV irradiation.

Author Contributions: G.S. synthesized and identified all the tested compounds. S.Q.L. studied their photochemical behavior at DQIAQF-FCEN-UBA while working at fabriQUIMICA under the responsibility of F.S. and with the direction of L.D. F.S. co-ordinated the joint research and wrote the initial version of the paper and subsequent corrections.

Acknowledgments: We thank the UDELAR (Uruguay) that allowed and financed the work of Gabriel Sagrera, INQUIMAE (CONICET-UBA) where all the photochemical measurements were done. Silvina Quintana and Federico Svarc to fabriQUIMICA S.R.L., which allowed us to take our time in this project while working in the company.

Conflicts of Interest: The authors declare no conflicts of interest. 


\section{References and Note}

1. Hossein-nezhad, A.; Holick, M.F. Vitamin D for health: A global perspective. Mayo Clin. Proc. 2013, 88, 720-755. [CrossRef] [PubMed]

2. Papoutsaki, M.; Costanzo, A. Treatment of psoriasis and psoriatic arthritis. BioDrugs 2013, $27,3-12$. [CrossRef] [PubMed]

3. Holick, M.F. Vitamin D and sunlight: Strategies for cancer prevention and other health benefits. Clin. J. Am. Soc. Nephrol. 2008, 3, 1548-1554. [CrossRef] [PubMed]

4. Narayanan, D.L.; Saladi, R.N.; Fox, J.L. Ultraviolet radiation and skin cancer. Int. J. Dermatol. 2010, 49, 979-986. [CrossRef] [PubMed]

5. Mason, R.S.; Reichrath, J. Sunlight, vitamin D and skin cancer. Anti-Cancer Agents Med. Chem. 2013, 13, 83-97. [CrossRef]

6. Pfeifer, G.P.; Besaratinia, A. UV wavelength-dependent DNA damage and human non-melanoma and melanoma skin cancer. Photochem. Photobiol. Sci. 2012, 11, 90-97. [CrossRef] [PubMed]

7. Shaat, N.A. Sunscreen evolution. In Sunscreens, Regulations and Commercial Development; Shaat, N.A., Ed.; Taylor \& Francis: Boca Raton, FL, USA, 2005; pp. 4-17.

8. Shaath, N.A. Ultraviolet filters. Photochem. Photobiol. Sci. 2010, 9, 464-469. [CrossRef] [PubMed]

9. Nash, J.F.; Tanner, P.R. Relevance of UV filter/sunscreen product photostability to human safety. Photodermatol. Photoimmunol. Photomed. 2014, 30, 88-95. [CrossRef] [PubMed]

10. Dondi, D.; Albini, A.; Serpone, N. Interactions between different solar UVB/UVA filters contained in commercial sunscreens and consequent loss of UV protection. Photochem. Photobiol. Sci. 2006, 5, 835-843. [CrossRef] [PubMed]

11. Schwack, W.; Rudolph, T. Photochemistry of dibenzoylmethane UVA filters, Part I. J. Photochem. Photobiol. $B$ 1995, 28, 229-234. [CrossRef]

12. Kockler, J.; Oelgemöller, M.; Robertson, S.; Glass, B.D. Influence of titanium dioxide particle size on the photostability of the chemical UV-filters butyl methoxydibenzoylmethane and octocrylene in a microemulsion. Cosmetics 2014, 1, 128-139. [CrossRef]

13. Svarc, F.E. A brief illustrated history on sunscreens and sun protection. Pure Appl. Chem. 2015, 87, 929-936. [CrossRef]

14. Karlsson, I.; Hillerstrom, L.; Stenfeldt, A.L.; Martensson, J.; Borje, A. Photodegradation of dibenzoylmethanes: Potential cause of photocontact allergy to sunscreens. Chem. Res. Toxicol. 2009, 22, 1881-1892. [CrossRef] [PubMed]

15. Sayre, R.M.; Dowdy, J.C.; Gerwig, A.J.; Shields, W.J.; Lloyd, R.V. Unexpected photolysis of the sunscreen octinoxate in the presence of the sunscreen avobenzone. Photochem. Photobiol. 2005, 81, 452-456. [CrossRef] [PubMed]

16. Forestier, S.; Lang, G.; Richard, H. Cosmetic Use of Dibenzoylmethane Diorganopolysiloxanes and Novel Cosmetic Compositions Containing such Compounds for Protection of Skin and Hair. U.S. Patent 5,145,662, 8 September 1992.

17. Bonda, C.A.; Marinelli, P.J.; Hessefort, Y.Z.; Trivedi, J.; Wentworth, G. Photostable Sunscreen Compositions Containing Dibenzoylmethane Derivative, e.g., Parsol@1789, and Diesters or Polyesters of Naphthalene Dicarboxylic Acid Photostabilizers and Enhancers of the Sun Protection Factor (SPF). U.S. Patent 5,993,789, 30 November 1999.

18. Hansenne, I.; Josso, M. Method for Providing Dibenzoylmethane Derivatives with Light Stability. U.S. Patent 6,569,409, 27 May 2003.

19. Lang, G.; Malaval, A. Procedimiento de Preparación de una Composición Cosmética Que contiene un Derivado del Dibenzoilmetano que incluye un Grupo cuaternario. Spanish Patent ES 504.560, 5 August 1981.

20. Asero, M.; Segal, A. Fotoestabilidad de avobenzona utilizando diferentes antioxidantes. In Proceedings of the 4th Argentine Congress of Cosmetic Chemistry (COARQC), Rosario, Argentina, 16-18 September 2016.

21. Zawadiak, J.; Mrzyczek, M. Influence of substituent on UV absorption and keto-enol tautomerism equilibrium of dibenzoylmethane derivatives. Spectrochim. Acta A Mol. Biomol. Spectrosc. 2012, 96, 815-819. [CrossRef] [PubMed] 
22. Wetz, F.; Routaboul, C.; Denis, A.; Ricco-Lattes, I. A new long-chain UV absorber derived from 4-tert-butyl-4'-methoxydibenzoilmethane: Absorbance stability under solar irradiation. J. Cosmet. Sci. 2005, 56, 135-148.

23. Tarras-Wahlberg, N.; Stenhagen, G.; Larko, O.; Rosen, A.; Wenneberg, A.M.; Wennerström, O. Changes in ultraviolet absorption of sunscreens after ultraviolet irradiation. J. Investig. Dermatol. 1999, 113, 547-553. [CrossRef] [PubMed]

24. Paris, C.; Lhiaubet-Vallet, V.; Jiménez, O.; Trullas, C.; Miranda, M.A. A blocked diketo form of avobenzone: Photostability, photosensitizing properties and triplet quenching by a triazine derived UVB-filter. Photochem. Photobiol. 2009, 85, 178-184. [CrossRef] [PubMed]

25. Gonzenbach, H. Photostability of Cosmetic sunscreens. In Pharmaceutical Photostability and Stabilization Technology; Piechocki, J., Thoms, K., Eds.; Informa Healthcare: New York, NY, USA, 2006; pp. 379-396.

26. Deflandre, A.; Lang, G. Photostability assessment of sunscreens. Benzylidene camphor and dibenzoylmethane derivatives. Int. J. Cosm. Sci. 1988, 10, 53-62. [CrossRef] [PubMed]

27. Lhiaubet-Vallet, V.; Marin, M.; Jimenez, O.; Gorchs, O.; Trullas, C.; Miranda, M.A. Filter-filter interactions. Photostabilization, triplet quenching and reactivity with singlet oxygen. Photochem. Photobiol. Sci. 2010, 9 , 552-558. [CrossRef] [PubMed]

28. Tovar-Sanchez, A.; Sanchez-Quiles, D.; Basterretxea, G.; Benede, J.L.; Chisvert, A.; Salvador, A.; Moreno-Garrido, I.; Blasco, J. Sunscreen products as emerging pollutants to coastal waters. PLoS ONE 2013, 8, e65451. [CrossRef] [PubMed]

29. Danovaro, R.; Bongiorni, L.; Corinaldesi, C.; Giovannelli, D.; Damiani, E.; Astolfi, P.; Greci, L.; Pusceddu, A. Sunscreens cause coral bleaching by promoting viral infections. Environ. Health Perspect. 2008, 116, 441-447. [CrossRef] [PubMed]

30. Downs, C.A.; Kramarsky-Winter, E.; Segal, R.; Fauth, J.; Knutson, S.; Bronstein, O.; Ciner, F.R.; Jeger, R.; Lichtenfeld, Y.; Woodley, C.M.; et al. Toxicopathological effects of the sunscreen UV filter, oxybenzone (benzophenone-3), on coral planulae and cultured primary cells and its environmental contamination in Hawaii and the U.S. Virgin Islands. Arch. Environ. Contam. Toxicol. 2016, 70, 265-288. [CrossRef] [PubMed]

31. Gago-Ferrero, P.; Diaz-Cruz, M.S.; Barcelo, D. An overview of UV-absorbing compounds (organic UV filters) in aquatic biota. Anal. Bioanal. Chem. 2012, 404, 2597-2610. [CrossRef] [PubMed]

32. Fent, K.; Kunz, P. Occurrence, and effects of hormonally active UV filters in the aquatic environment. SOFW 2009, 135, 2-12.

33. Poiger, T.; Buser, H.R.; Balmer, M.E.; Bergqvist, P.A.; Muller, M.D. Occurrence of UV filter compounds from sunscreens in surface waters: Regional mass balance in two Swiss lakes. Chemosphere 2004, 55, 951-963. [CrossRef] [PubMed]

34. Giokas, D.L.; Salvador, A.; Chisvert, A. UV filters: From sunscreens to human body and the environment. Trends Anal. Chem. 2007, 26, 360-374. [CrossRef]

35. Forestier, S.; Moire, C.; Lang, G. Preparation of Chalcone Derivatives as Sunscreens. Ger. Offen. DE 3742690 A1 19880630, 30 June 1988.

36. Imokawa, G.; Takaishi, N.; Tejima, T.; Nakamura, K.; Hattori, M.; Masuda, S. Chalcone Derivatives and an Ultraviolet Absorber Containing Them. Ger. Offen. DE 3441636 A1 19850530, 20 October 1995.

37. Fujii, A.; Sashita, Y.; Mimaki, Y.; Matsubara, K.; Hara, R.; Kitada, Y.; Nakajima, T.; Oosato, Y.; Oohata, S.; Myata, Y. 2,4,6-Trihydroxychalcone as a UV Absorbing Agent and Cosmetics Containing it. Jpn. KokaiTokkyoKoho. JP 08113521 A19960507, 7 May 1996.

38. Okuya, F.; Nishio, H.; Kuwamura, S.; Deguchi, Y. ChalconeDerivatives and Copolymers Thereof as UV Absorbers. Jpn. KokaiTokkyoKoho. JP 05263067 A 19931012, 12 October 1993.

39. Lahorkar, P.G.R.; Vaidya, A.A.; Chavan, M.V.; Gadgil, V.R. A Photoprotective Personal Care Composition. PCT Int. Appl. WO 2014191143-A1 20141204, 4 December 2014.

40. Sagrera, G.; Bertucci, A.; Vazquez, A.; Seoane, G. Synthesis and antifungal activities of natural and synthetic biflavonoids. Bioorg. Med. Chem. 2011, 19, 3060-3073. [CrossRef] [PubMed]

41. Sagrera, G. Síntesis de nuevos dibenzoilmetanos como potenciales filtros solares. In Proceedings of the XXII Latin American and Iberian Congress of Cosmetic Chemists, Punta del Este, Uruguay, 27-29 October 2015.

42. Berger, D. Solar UV simulator skin testing. In Cosmetics and Toiletries Manufacture Worldwide; PA 19126-3331; Solar Light Co.: Philadelphia, PA, USA, 2003; pp. 255-257. 
43. Wilkinson, F.; Helman, W.P.; Ross, A.B. Rate constant for the decay and reactions of the lowest electronically excited singlet state of molecular oxygen in solution. J. Phys. Chem. 1995, 24, 663-1021. [CrossRef]

44. Calzadilla, P.; Sapochnik, D.; Cosentino, S.; Diz, V.; Dicelio, L.E.; Calvo, J.C.; Guerra, L.N. N-acetylcysteine reduces markers of differentiation in 3T3-L1 adipocytes. Int. J. Mol. Sci. 2011, 12, 6936-6951. [CrossRef] [PubMed]

45. Strassert, C.A.; Bilmes, G.M.; Awruch, J.; Dicelio, L.E. Comparative photophysical investigation of oxygen and sulfur as covalent linkers on octaalkylamino substituted zinc(II) phthalocyanines. Photochem. Photobiol. Sci. 2008, 7, 738-747. [CrossRef] [PubMed]

46. Global Solar UV Index. Available online: http://www.who.int/uv/publications/globalindex/en/ (accessed on 9 February 2017).

47. Amor, S.; Angeli, N.G.; Dicelio, L.E. Fotoestabilidad de Filtros Solares. In Proceedings of the XXVII Meeting of the Argentine Society of Cosmetic Chemists (AAQC), Pinamar, Argentina, 3-5 November 2000.

48. Kavanaugh, E. Tentative Final Monograph for OTC Sunscreen Drug Products: Docket No. 78N0038; The Cosmetic, Toiletry, and Fragrance Association (CTFA): Washington, DC, USA, 1998.

49. COLIPA Project Team IV. Guideline 2007a. Method for the in vitro Determination of UVA Protection Provided by Sunscreen Products. The European Cosmetic, Toiletry and Perfumery Association. Bruselles 2007.

50. Margarida, S.M.; Pinto da Silva, L.; Esteves da Silva, J.C.G. UV Filter 2-ethylhexyl 4-methoxycinnamate: A structure, energetic and UV-vis spectral analysis based on density functional theory. J. Phys. Org. Chem. 2014, 27, 47-56. [CrossRef]

(C) 2018 by the authors. Licensee MDPI, Basel, Switzerland. This article is an open access article distributed under the terms and conditions of the Creative Commons Attribution (CC BY) license (http:/ / creativecommons.org/licenses/by/4.0/). 